\title{
EFFICIENCY EVALUATION \\ OF APARTMENT HOUSES RECONSTRUCTION WITH OPTIMIZATIONAL CRITERIA APPLICATION
}

\author{
Alexander N. Biryukov ${ }^{1}$, Igor N. Kravchenko ${ }^{2}$, Evgeny O. Dobryshkin ${ }^{1}$, \\ Yuri A. Biryukov ${ }^{1}$, Valery I. Kondrashchenko ${ }^{3}$ \\ ${ }^{1}$ Military Academy of Logistics named after Army General A.V. Khrulev, Saint-Petersburg, RUSSIA \\ ${ }^{2}$ Russian State Agrarian University - Moscow Agricultural Academy named after K.A. Timiryazev, \\ Moscow, RUSSIA \\ ${ }^{3}$ Russian University of Transport, Moscow, RUSSIA
}

\begin{abstract}
The subject of the study, considered in the article, is the technical condition of the housing stock of the Russian Federation, which is a totality of objects with a characteristic variety of structural and space-planning decisions and increased values of physical wear. The objective of the study conducted by the authors was to develop an optimization criterion for assessing the effectiveness of restoration of housing facilities based on determining the ratio of one-time costs for restoration work and current projected costs for operation and maintenance of an apartment house. Since an important stage in reproduction of the housing stock is preparation of design estimates for reasonable implementation of capital investments by property owners and government support measures for restoration of buildings, the topic discussed in this article is relevant. The scientific novelty of the study conducted by the authors is to develop a method for assessing the effectiveness of overhaul (reconstruction, modernization) of buildings, where the criterion is the choice of innovative design solutions and building materials when planning the restoration of housing facilities.
\end{abstract}

Keywords: housing stock, housing facilities, restoration, overhaul, reconstruction, modernization, variant design

\section{ОЦЕНКА ЭФФЕКТИВНОСТИ РЕКОНСТРУКЦИИ ЖИЛЫХ ДОМОВ С ПРИМЕНЕНИЕМ ОПТИМИЗАЦИОННОГО КРИТЕРИЯ}

\author{
А.Н. Бирюков ${ }^{1}$, И.Н. Кравченко ${ }^{2}$, Е.О. Добрышкин ${ }^{1}$, Ю.А. Бирюков ${ }^{1}$, \\ В.И. Кондращенко ${ }^{3}$ \\ ${ }^{1}$ Военная академия логистики имени генерала армии А.В. Хрулева, г. Санкт-Петербург, РОССИЯ \\ ${ }^{2}$ Российский государственный аграрный университет - Московская сельскохозяйственная академия \\ им. К.А. Тимирязева, г. Москва, РОССИЯ \\ ${ }^{3}$ Российский университет транспорта, г. Москва, РОССИЯ
}

\begin{abstract}
Аннотация. Предметом исследования, рассматриваемого в статье, является техническое состояние жилого фонда Российской Федерации, представляющего собой совокупность объектов с характерным разнообразием конструктивных и планировочных решений и повышенными значениями физического износа. Целью исследования, проведенного авторами, была разработка оптимизационного критерия оценки эффективности восстановления объектов жилья на основе определения соотношения разовых затрат на восстановительные работы и текущих проектных затрат на эксплуатацию и содержание жилого дома. Поскольку важным этапом восстановления жилого фонда является подготовка проектно-сметной документации для обоснованного осуществления капитальных вложений собственниками и меры государственной поддержки для восстановления зданий, тема, обсуждаемая в этой статье, является актуальной. Научная новизна исследования, проведенного авторами, заключается в разработке метода оценки эффективности капитального ремонта (реконструкции, модернизации) зданий, где критерием является выбор инновационных проектных решений и строительных материалов при планировании восстановления объектов жилья.
\end{abstract}


Efficiency Evaluation of Apartment Houses Reconstruction with Optimizational Criteria Application

\begin{abstract}
Ключевые слова: жилищный фонд, объекты жилья, реставрация, капитальный ремонт, реконструкция, модернизация, вариантное проектирование
\end{abstract}

\section{INTRODUCTION}

Currently, the legislation of the Russian Federation defines housing stock as a totality of all residential premises located on the territory of the Russian Federation [1].

In the context of the reform of infrastructure sectors of the economy in the Russian Federation, one of the most important tasks is implementation of socio-economic transformations in the Russian Federation, and mainly in the housing and communal sector, since market and administrative approaches are particularly acute in this sector. Therefore, it is difficult to find a compromise between economic feasibility of restoring residential buildings, the ability of owners to provide proper control over implementation of work, as well as the ability of the state to provide financial support to owners in order to create a comfortable urban environment [2].

However, the growing degradation of the housing stock in the Russian Federation, the disordered legal relationships in it put society and the state in need of making drastic decisions and taking measures aimed at improving the current situation with the technical condition of residential buildings in the country. This problem becomes particularly urgent in the context of regular amendments to the Housing Code of the Russian Federation, within the framework of which the powers of participants are expanded when managing an apartment house, responsibility is transferred for their (apartment houses) maintenance to the owners of premises, and the role of state and municipal authorities is changing in the housing and communal services market.

Important is the fact that the housing stock of the Russian Federation is characterized by a historically developed variety of constructive and space-planning decisions (Table 1). The building of a significant number of cities on the territory of the Russian Federation has a long history and is characterized by increased values of development of physical wear of building structures.

Thus, the housing stock of the Russian Federation totals about 3 billion square meters of total area, which makes up more than $30 \%$ of all reproducible property. At the present stage, deterioration of the housing stock of most Russian cities is about 70\%. Residential buildings that have been in operation in disrepair for more than 25 years without restoration work represent about 300 million square meters [3]. Housing facilities subject to demolition due to an emergency technical condition make up about 90 million square meters $(3,2 \%$ of the total housing area), where according to rough estimates about 5 million citizens of the Russian Federation live [3].

It will be advisable to consider in more detail the technical condition of residential buildings on the example of Leningrad region, since building of this constituent entity of the Russian Federation has been formed for more than 300 years of formation of the state in the European part of Russia and for 2017 consisted of 18,127 apartment houses. It is necessary to bring some clarity to the concept of "apartment house" (since these buildings are a structural component of the country's housing stock) in accordance with the explanations of the Ministry of Economic Development of the Russian Federation, according to which any residential building with more than one apartment is an apartment house [4].

At the present stage, $42 \%$ of houses or $64 \%$ of the total area of apartment houses in Leningrad region were built in the period 1971-1995, and $2 \%$ of the total area of apartment houses are characterized by the presence of wooden walling (Figures 1, 2) [5].

The current legislation of Leningrad region provides for annual collection of data on the technical condition of apartment houses [6]. 
Alexander N. Biryukov, Igor N. Kravchenko, Evgeny O. Dobryshkin, Yuri A. Biryukov, Valery I. Kondrashchenko

Table 1. Design schemes of residential buildings of old construction in Saint-Petersburg.

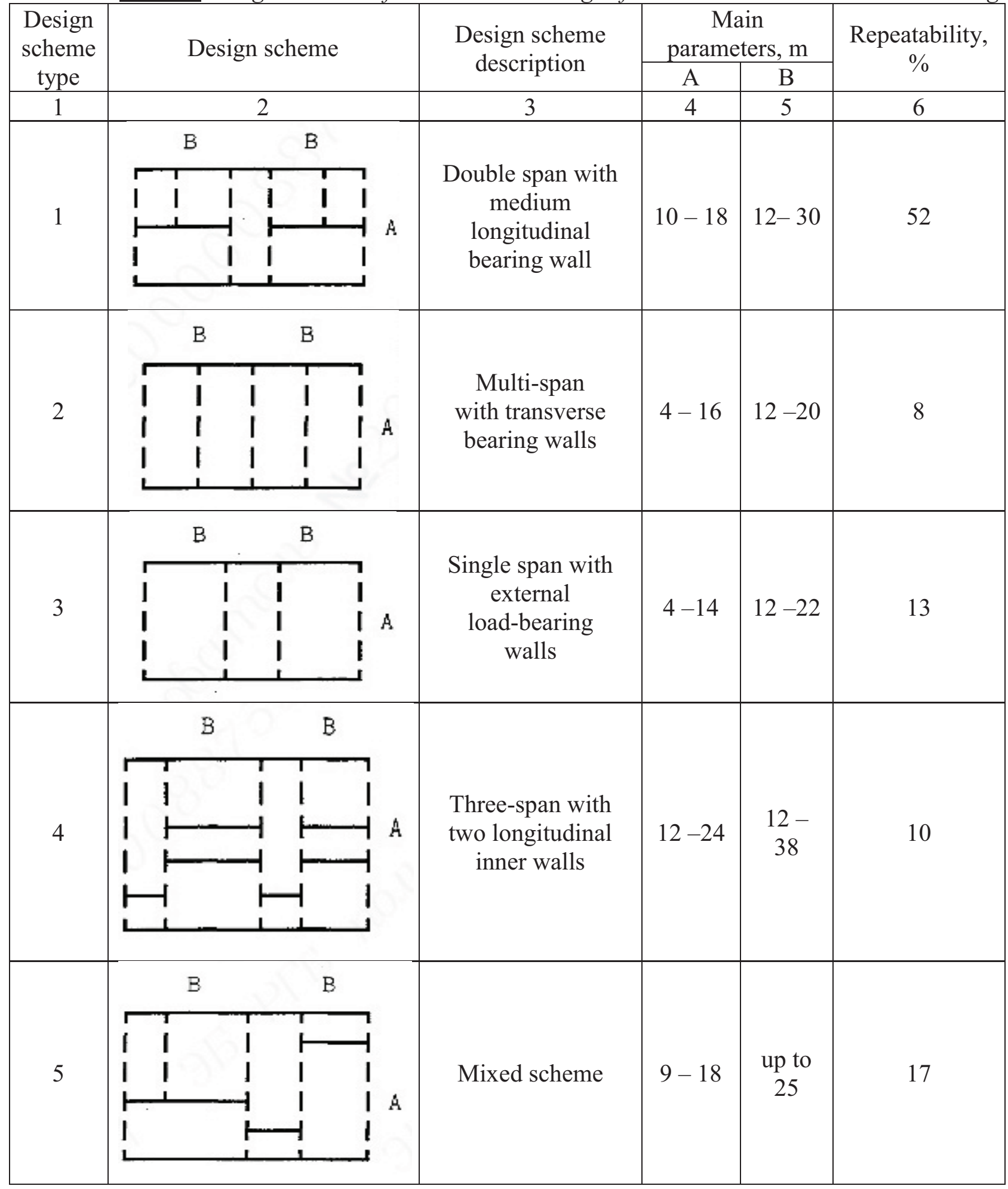

The authors of the article analyzed the technical condition of 12981 housing facilities. The results obtained by the authors allow us to conclude that a significant number of buildings in emergency condition with increased values of physical wear are in operation: 


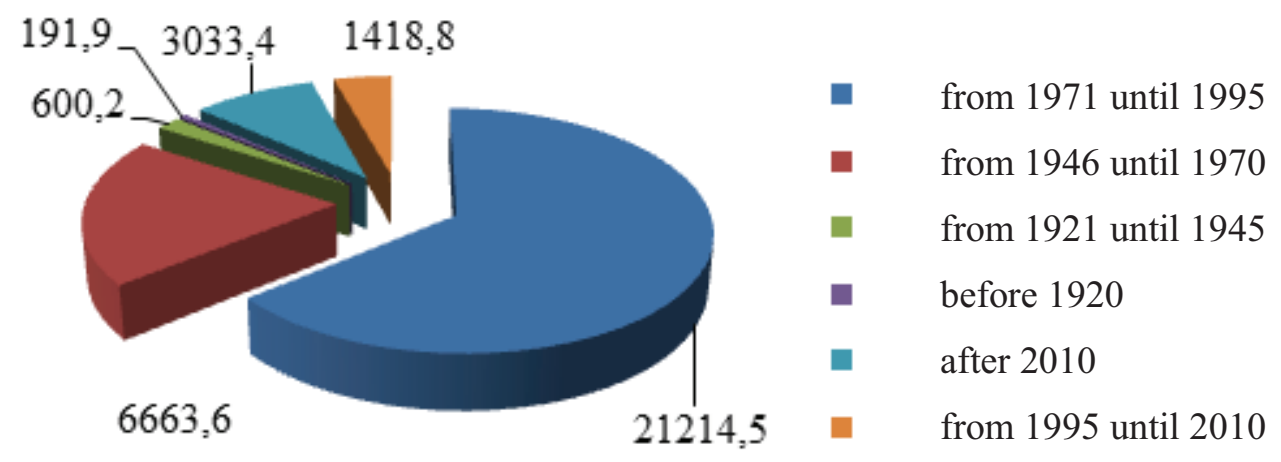

Figure 1. Analysis of the housing stock of Leningrad region by year of construction, $m^{2}$.

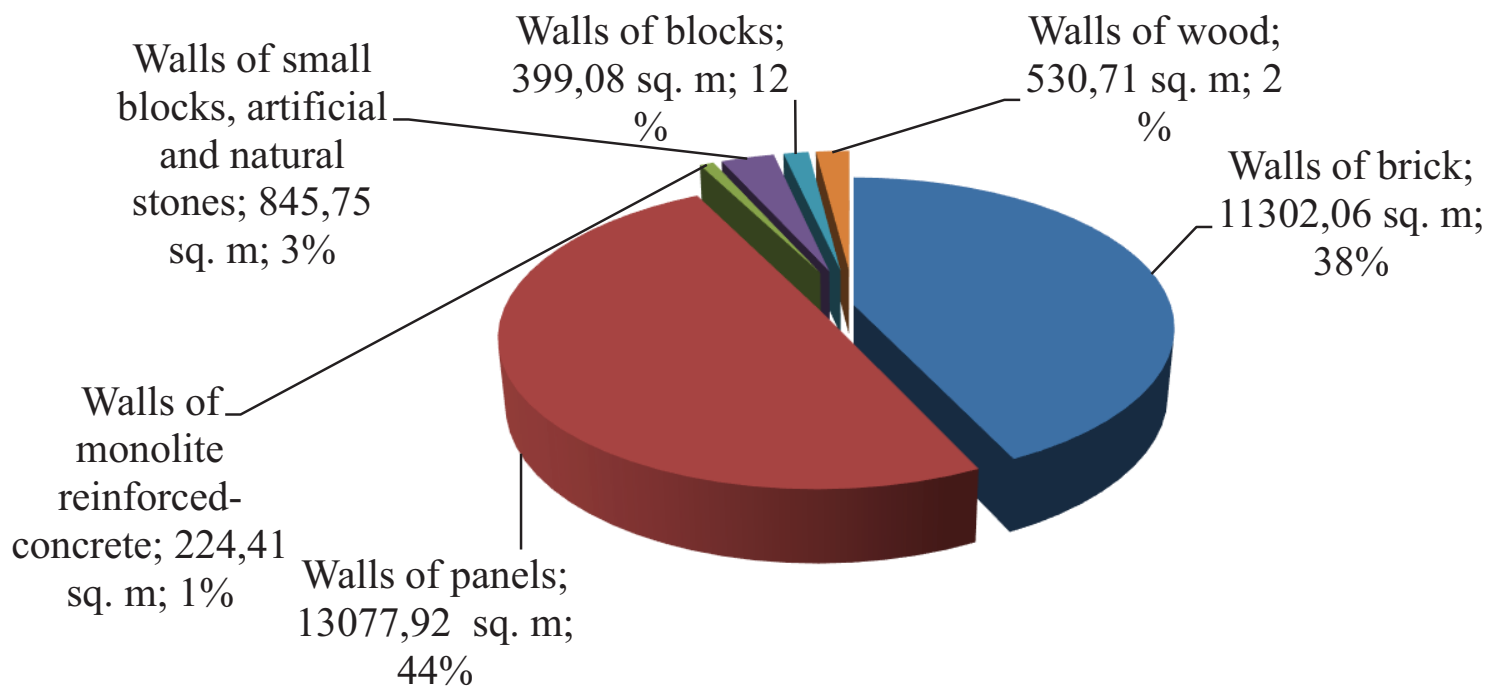

Figure 2. Classification of the housing stock of Leningrad region by the material of walls, $\mathrm{m}^{2}$.

$0-20 \%-1660$ apartment houses with total area of 7626,2 thous. $\mathrm{m}^{2} ; 21-40 \%-3341$ apartment houses 9603,5 thous. $\mathrm{m}^{2} ; 41-70 \%-3387$ apartment houses 5417,6 thous. $\mathrm{m}^{2}$; over $70 \%-$ 988 apartment houses 1091,2 thous. $\mathrm{m}^{2}$.

The largest number of apartment houses with a physical depreciation value of more than $70 \%$ are in Slantsevsky and Volkhovsky districts (38\% and $20 \%$ of the total, respectively). The analysis of the technical condition of structural elements of 12981 apartment houses performed by the authors shows that $30 \%$ of foundations, $31 \%$ of roofing, $35 \%$ of facades require major repairs [6].

\section{MATERIALS AND METHODS}

In the course of the study, the authors determined that overhaul should be considered as one of the ways to preserve and update the housing stock along with current repair, reconstruction, modernization and new construction [7, 8, 9]. Moreover, in the absence of economic feasibility of repairs and reconstruction of buildings, preference should be given in favor of new construction. However, new construction often requires demolition of emergency apartment houses, which entails the need for resettlement of residents, while during overhaul or reconstruction, resettlement of owners is carried out only with comprehensive performance of 
restoration work. It is advisable to organize reproduction of the housing stock by demolishing old facilities and new construction when the high level of physical wear of residential buildings does not allow the efficient use of capital investments of owners and state support funds for reconstruction work. In addition, demolition of old buildings, design, preparation of the territory and construction itself significantly increases commissioning time and cost of the future building $[10,11]$. Thus, overhaul costs are 30-35\%, modernization - 50$55 \%$, reconstruction $-60-70 \%$ of the cost of $1 \mathrm{~m}^{2}$ of the total area for new construction according to the Russian Academy of Architecture and Building Sciences [12]. Therefore, given the current state of the housing stock in the Russian Federation, the most appropriate is reproduction of housing through overhaul, reconstruction and modernization, implementation of these processes in the framework of this article, the authors accept as restoration work to eliminate physical wear of an apartment house.

One of the main stages of reconstruction of the housing stock by means of overhaul, reconstruction and modernization is preparation of design estimates for all design decisions on redevelopment, functional reassignment of premises, replacement of structures, engineering systems or their installation again, landscaping and other similar work. As part of the study, the authors used the analytical method and deduction, it was determined that a significant number of scientists whose scientific results were analyzed and summarized when writing the article were involved in the study of the issue of efficiency in implementation of investment construction projects (including reconstruction and overhaul projects $[13,14,15]$.

\section{RESEARCH RESULTS AND DISCUSSION}

In the framework of the study, the authors developed an approach to implementation of planning for restoration work based on variant design (Figure 3).
In accordance with the algorithm developed by the authors, preparation of projects for restoration of an apartment house should be preceded by a survey of the apartment house in order to determine the category of technical condition based on $[16,17]$.

The effectiveness of planning the reconstruction of the housing stock can be achieved by evaluating the restoration projects (overhaul, reconstruction or modernization) of the housing stock. It is advisable to accomplish this task by comparing variation of one-time and current costs when implementing a project for restoration of an apartment house on the basis of the following: increasing one-time costs of restoring a building to a certain level leads to a decrease in subsequent current costs for operation and maintenance (Figure 4) [ 11, 12].

So, overhaul of the facade of an apartment house can be carried out according to the standard option, i.e. sealing the external joints of a closely located urban area, repairing plaster and painting the facade, and an external insulation system using hinged ventilated facades can be used [18, 19].

The advantages of the latter option are reduction of heat losses, increase in the service life of loadbearing enclosing structures by eliminating condensation of water vapor in the load-bearing wall, possibility of reconstructing a house without resettling residents, and reducing the cost of repairing building envelopes, since the system in question plays the role of corrosion protection [20]. The key factor that determines the use of the system of ventilated facades is to increase durability and service life in relation to the standard overhaul period of operation of the facade in traditional stucco finishing.

In order to compare projects for restoration of an apartment house proposed for implementation, it is necessary to introduce a number of designations.

We will take $K_{i}$ as one-time costs of restoration of a building in accordance with the $i$-th project for restoration of an apartment house. 




Figure 3. Algorithm of planning of restoration works based on variant design.



Figure 4. Graph of dependence between current and one-time costs ( $K$-one-time costs, $Z$-current costs).

We will consider $S_{v i}$ as operating costs for maintenance of an apartment house for the $v$-th year of operation $(v=1,2,3, \ldots, g)$ during implementation of the $i$-th project of restoration of a house, and $C_{v i}-$ costs of ongoing repairs, if necessary, for the $v$-year year of operation of the house during implementation of the $i$-th project. Then the effectiveness of the building restoration project can be determined by the ratio of the sum of the costs of operation and maintenance to the number of one-time costs of the project:

$$
P_{i}=\frac{K_{i}}{S_{i}+C_{i}}
$$


At the same time, planning of current repairs and distribution of costs for operation of an apartment house are carried out for a certain period of time after restoration of the housing stock, which sets the task of taking into account annual inflation in assessing the effectiveness of restoration projects for an apartment house. Then the costs of the current repair and maintenance of the apartment house will be set in the form:

$$
S_{v i}(1+p)^{v-1}
$$

and

$$
C_{v i}(1+p)^{v-1}
$$

where $p$ - inflation in fractions of a unit, taken for the $v$-th year of operation of the housing stock after its restoration.

Then the criterion for effectiveness of the projects under consideration for the accepted horizon of calculation (in years) should be determined by the following mathematical expression:

$$
P I=\frac{K_{i}}{e_{v=1}^{g}\left(S_{v i}(1+p)^{v-1}+C_{v i}(1+p)^{v-1}\right)}
$$

Thus, the decision to restore apartment houses on the basis of variant design allows the selection of projects for restoration of housing facilities with the highest $P I$ values. The next stage of work planning in accordance with the algorithm developed by the authors (Figure 3) is to determine the share of owners in implementation of the corresponding project and the amount of state support in restoration of an apartment house. The key point of the considered stage is selection of the contractor in accordance with the lowest price criterion $[21,22]$ during the auction, and at the same time, the quality of contractor work to comply with the interests of the owners (in the form of ensuring a quality standard of living for citizens) and the interests of the state (with formation of the comfortable urban environment). The ultimate goal of the process in question is to implement the project and reduce the level of physical wear of the housing facility.

\section{CONCLUSIONS}

As a result of the study, it was determined that an increase to a certain level of one-time costs for restoration of an apartment house allows to increase the overhaul periods of operation, which allows to reduce the amount of costs for the current repair of the building. In addition, the choice of innovative design solutions and building materials when planning restoration of housing facilities can reduce the costs of current operation of an apartment house, since in the long run, taking into account inflation, the cost of operating an apartment house requires a significant amount of investment. Since the owner will continue to bear the costs of current maintenance of an apartment house, he is interested in optimizing the consumption of fuel and energy resources as a result of restoration (major repairs, reconstruction or modernization) and minimizing the loss of heat and other energy, as well as reducing operational housing facility expenses. The results of the scientific research of the authors are especially relevant in view of the fact that the current stage of the need to improve the energy efficiency of buildings is one of the key tasks facing the world scientific community in a number of countries.

\section{REFERENCES}

1. Zhilishchnyi kodeks Rossiiskoy Federacii ot 29.12.2004 g. № 188-FZ [Housing code of the Russian Federation of 29.12.2004 № 188-FZ] (v red. ot 22.01.2019) [in the wording 22.01.2019] (in Russian).

2. Yakuntsev D.S. Organizacionnoeconomicheskiy mechanism predostavleniya uslug kapital'nogo remonta mnogokvartinyh domov [The organizational and economic mechanism of providing services of apartment houses capital repairs]. Diss. kand. ekonom. nauk [Dissertation of economical science]. Moscow, Izd. dom Moskovskogo institute 
kommunalnogo khozyaistva i stroitel'stva, 2008, 155 pages (in Russian).

3. Federal State Statistics Service [Electronic resource, Section "Housing conditions"]. URL: http://www.gks.ru (Accessed 15.10.2018).

4. Vopros: Ob osobennostyah gosudarstvennoi registracii prav na nekotorye ob'ekty nedvizhimosti, a takzhe priznakah otnesenyia ob'ekta nedvizhimosti $\kappa$ mnogokvartitnym zhilym domam [Question: about the features of the state registration of rights to some real estate objects, as well as signs of attributing the property to apartment houses]. Pis'mo Minekonomrazvitiya RF ot 23.06.2010 No. D23-2280 [Letter of the Russian Federation Ministry of economic development of 23.06.2010 № D23-2280]. \{Consultant Plus \} (in Russian).

5. Doklad o tehnicheskom sostoyanii mnogokvartirnyh domov, raspologennyh na territorii Leningradskoy oblasti [Report on the technical condition of apartment buildings located in the Leningrad region]. Komitet gosudarstvennogo zhilichnogo nadzora i kontrolya Leningradskoy oblasti, Pravitel'stvo Leningradskoy oblasti [Committee of state housing supervision and control of the Leningrad region, the government of the Leningrad region], 2017, 22 pages (in Russian).

6. Oblastnoy zakon Leningradskoy oblasti ot 29.11.2013 No. FZ-O3 "Ob otdelnyh voprosah organizacii i provedeniya kapital'nogo remonta obschego imuchestva v mnogokvartirnyh domah, raspologennyh na territorii Leningradskoy oblasti" [Regional law of the Leningrad region of 29.11.2013 No. 82-OZ "On certain issues of organization and overhaul of common property in multi-apartment buildings located in the Leningrad region"]. Red. ot 29.12.2018 [Edited on 29.12.2018] (in Russian).

7. Chernyshov L.N., Astaf'ev S.A., Vakulina V.P. Kapitalnyi remont mnogokvartirnyh domov: problemy formirovaniya i napravleniya razvitiya [Capital repair of apartment buildings: problems of formation and direction of development]. // Izvestiya Irkutskoy gosudarstvennoy ekonomicheskoy akademii, 2015, No. 25, Vol. 1, pp. $85-94$ (in Russian).

8. Nurullina O.V. Zhilishchniy fond: metodika otbora domov dlya okazaniya remontnyh eslug [Housing stock: methods of selecting houses to provide repair services]. // Rossiskoe predprinimatelstvo, 2011, No. 12(1), pp. 135-140 (in Russian).

9. Kashina E.V., Stepanova A.V. Analiz i ozchenka mehanizmov razvitiya modelei vosproizvodstva zhilichnogo fonda [Analysis and evaluation of development mechanisms of housing reproduction models]. Izvestiya vuzov. Stroitel'stvo. Neddvizhimost', 2016, No. 3(18), pp. 22-27 (in Russian).

10. Biryukov A.N. Osnovnye organizacionnotehnologichskie resheniya i economicheskaya celesoobraznost' snosa zdanii [The main organizational and technological solutions and economic feasibility of building demolition]. Vestnik grazhdanskih inzhenerov, 2012, No. 5, p. 103-109 (In Russian).

11. Biryukov A.N., Denisov V.N., Biryukov Yu.A. Snos zdanii i sooruzheii v sovremennyh usloviyah (monographiya) [Demolition of buildings and structures in modern conditions]. Saint-Petersburg, 2014, 256 pages (in Russian).

12. Andreev A.S., Arkhipov V. L., Biryukov A. N., Bulanov A.I., Biryukov Yu. A., Kulikov D. N., Ivanov D. V. Ekonomika stroitelstva [Economics of construction]. Saint-Petersburg, 2016, 370 pages (in Russian).

13. Ustinovichius L. Determination of efficiency of investments in construction. // International Journal of Strategic Property Management, 2004, No. 8, Vol. 1, pp. 25-43.

14. Farahani A., Wallbaum H., Dalenbäck J.O. Optimized maintenance and renovation 
Alexander N. Biryukov, Igor N. Kravchenko, Evgeny O. Dobryshkin, Yuri A. Biryukov, Valery I. Kondrashchenko

scheduling in multifamily buildings - a systematic approach based on condition state and life cycle cost of building components. // Construction Management and Economics, 2018, No. 11, pp. 1-17.

15. Zavadskas E.K., Turskis Z., Tamošaitiene J. Risk assessment of construction projects. // Journal of Civil Engineering and Management, 2010, No. 16, Vol. 1, pp. 33-46.

16. Biryukov A.N., Marugin V.M., Lazarev A.N., Moroz A.M., Chmyrev V.A. Ekspertnye formy kontrolya (na primerah ocenki stroitelnyh ob'ektov i samoocenki stroitelnyh predpriyatii) (monographiya) [Expert forms of control (on the evaluation of construction projects and self-assessment of construction enterprises]. SaintPetersburg, Izdatel'stvo 'Politekhnika", 2012, 213 pages (in Russian).

17. GOST 31937-2011 ot 27 dekabrya 2012 goda [GOST 31937-2011 of December 27, 2012] "Zdaniya i sooruzheniya. Pravila obsledovaniya i monitoring tekhnicheskogo sostoyaniya" [Buildings and structures. Rules of inspection and monitoring of technical condition»] (in Russian).

18. Biryukov A.N., Kazakov Yu.N. Effektivnost' novoi tehnologii ustroistva navesnyh ventiliruemyh fasadov [Efficiency of new technology of ventilated facades]. // Materialy 11-i Mezhdunarodnoi nauchnopractichskoi conferencii «Novosti peredovoi nauki» [Materials of the 11th International scientific and practical conference "News of advanced science»], 2015, Vol. 17. Tekhnologii. Stroitel'stvo i arkhitektura. Sofia, "Beliy gorod BG", pp. 79-84 (in Russian).

19. Biryukov A., Kazakov Y. Fast assembly of quality suspended ventilated facades. // Architecture and Engineering, 2017, No. 2, Vol. 1, pp. 11-19.

20. Biryukov A.N., Denisov V.N., Shvarts M.S. Rol' teplovoy inercii $\mathrm{V}$ zachite ograzhdauychih konstrukcii ot promerzaniya $\mathrm{v}$ sibirskih regionah [The role of thermal inertia in the protection of enclosing structures from freezing in the Siberian regions]. // Stroitel'nyue $i$ dorozhnyue mashiny, 2016, No. 3, pp. 45-50 (in Russian).

21. González-Cruz C. Scoring rules and abnormally low bids criteria in construction tenders: a taxonomic review. // Construction Management and Economics, 2015, No. 33, Vol. 4, pp. 259-278.

22. Zeiler W., Gvozdenović K., De Bont K., Maassen W. Toward cost-effective nearly zero energy buildings: The Dutch Situation. // Science and Technology for the Built Environment, 2016, No. 22, Vol. 7, pp. 911927.

23. Melnikas B., Jakubavičius A., Strazdas R. The Development of innovation activities in building construction by saving heating resources. // Statyba, 1998, No. 4, Vol. 3, pp. 235-242.

24. Berg F., Fuglseth M. Life cycle assessment and historic buildings: energy-efficiency refurbishment versus new construction in Norway. // Journal of Architectural Conservation, 2018, No. 24, Vol. 2, pp. 152167.

\section{REFERENCES}

1. Жилищный кодекс Российской Федерации (Федеральный закон (ФЗ) от 29 декабря 2004 г. №188-Ф3 (в редакции от 22 января 2019 г.).

2. Якунцев Д.С. Организационноэкономический механизм предоставления услуг капитального ремонта многоквартирных домов. Диссертация на соискание ученой степени кандидата экономических наук по специальности 08.00.05 - Экономика и управление народным хозяйством (экономика, организация и управление предприятиями, отраслями, комплексами - сфера услуг; экономика, организация и управление предприятиями, отраслями, комплексами - строительство. - M.: 
Efficiency Evaluation of Apartment Houses Reconstruction with Optimizational Criteria Application

Российский государственный университет туризма и сервиса, 2008. $155 \mathrm{c}$.

3. Интернет-сайт Федеральной службы государственной статистики. URL: http://www.gks.ru (Дата доступа: 15 октября 2018 г.).

4. Вопрос: Об особенностях государственной регистрации прав на некоторые объекты недвижимости, а также признаках отнесения объекта недвижимости к многоквартирным жилым домам. Письмо Минэкономразвития России от 23 июня 2010 г. № Д23-2280.

5. Доклад о техническом состоянии многоквартирных домов, расположенных на территории Ленинградской области. Комитет государственного жилищного надзора и контроля Ленинградской области, 2017. - 22 с.

6. Областной закон Ленинградской области от 29 ноября 2013 г. №Ф3-ОЗ «Об отдельных вопросах организации и проведения капитального ремонта общего имущества в многоквартирных домах, расположенных на территории Ленинградской области» (редакция от 29 декабря 2018 г.).

7. Чернышов Л.Н., Астафьев С.А., Вакулина В.П. Капитальный ремонт многоквартирных домов: проблемы формирования и направления развития. // Известия Иркутской государственной экономической академии, 2015, том 25, №1, c. 85-94.

8. Нуруллина О.В. Жилищный фонд: методика отбора домов для оказания ремонтных услуг. // Российское предпринимательство, 2011, №12(1), с. 135-140.

9. Кашина Е.В., Степанова А.В. Анализ и оценка механизмов развития моделей воспроизводства жилищного фонда. // Известия высиих учебных заведений. Строительство. Недвижимость, 2016, №3(18), c. 22-27.
10. Бирюков А.Н. Основные организационно-технологические решения и экономическая целесообразность сноса зданий. // Вестник гражданских инженеров, 2012, №5, c. 103-109.

11. Бирюков А.Н., Денисов В.Н., Бирюков Ю.А. Снос зданий и сооружений в современных условиях. - СПб, 2014. - 256 с.

12. Андреев А.С., Архипов В.Л., Бирюков А.Н., Буланов А.И., Бирюков Ю.А., Куликов Д.Н., Иванов Д.В. Экономика строительства. - СПб., 2016. - 370 с.

13. Ustinovichius L. Determination of efficiency of investments in construction. // International Journal of Strategic Property Management, 2004, No. 8, Vol. 1, pp. 25-43.

14. Farahani A., Wallbaum H., Dalenbäck J.O. Optimized maintenance and renovation scheduling in multifamily buildings - a systematic approach based on condition state and life cycle cost of building components. // Construction Management and Economics, 2018, No. 11, pp. 1-17.

15. Zavadskas E.K., Turskis Z., Tamošaitiene J. Risk assessment of construction projects. // Journal of Civil Engineering and Management, 2010, No. 16, Vol. 1, pp. 33-46.

16. Бирюков А.Н., Маругин В.М., Лазарев А.Н., Мороз А.М., Шмырев В.А. Экспертные формы контроля (на примерах оценки строительных объектов и самооценки строительных предприятий). - СПб.: Издательство «Политехника», 2012. - 213 с.

17. ГОСТ 31937-2011 «Здания и сооружения. Правила обследования и мониторинга технического состояния» (редакция от 27 декабря 2012 г.).

18. Бирюков А.Н., Казаков Ю.Н. Эффективность новой технологии устройства навесных вентилируемых фасадов. // Материальь одиннадиатой научно-практической конференции «Новости передовой науки», 2015, №17, Технологии. Строительство и архитектура. - София: Белый город БГ, с. 79-84. 
Alexander N. Biryukov, Igor N. Kravchenko, Evgeny O. Dobryshkin, Yuri A. Biryukov, Valery I. Kondrashchenko

19. Biryukov A., Kazakov Y. Fast assembly of quality suspended ventilated facades. // Architecture and Engineering, 2017, No. 2, Vol. 1, pp. 11-19.

20. Бирюков А.Н., Денисов В.Н., Шварц М.С. Роль тепловой инерции в защите ограждающих конструкций от промерзания в сибирских регионах. // Строительные и дорожные машины, 2016, №3, c. 45-50.

21. González-Cruz C. Scoring rules and abnormally low bids criteria in construction tenders: a taxonomic review. // Construction Management and Economics, 2015, No. 33, Vol. 4, pp. 259-278.

22. Zeiler W., Gvozdenović K., De Bont K., Maassen W. Toward cost-effective nearly zero energy buildings: The Dutch Situation. // Science and Technology for the Built Environment, 2016, No. 22, Vol. 7, pp. 911-927.

23. Melnikas B., Jakubavičius A., Strazdas R. The Development of innovation activities in building construction by saving heating resources. // Statyba, 1998, No. 4, Vol. 3, pp. 235-242.

24. Berg F., Fuglseth M. Life cycle assessment and historic buildings: energy-efficiency refurbishment versus new construction in Norway. // Journal of Architectural Conservation, 2018, No. 24, Vol. 2, pp. 152-167.

Alexander N. Biryukov, Doctor of technical sciences, professor, chief of department, Military Institute (engineering), Military Academy of Logistics named after Army General A.V. Khrulev, Zakharyevskaya st., 22, St. Petersburg, 191123, Russian Federation;

Phone: +7 (921) 751-67-52; e-mail: aleks_bir@mail.ru.

Igor N. Kravchenko, Doctor of technical sciences, professor, professor of the Department of Technical Service of Machinery and Equipment, Russian State Agrarian University-Moscow Agricultural Academy named after K.A. Timiryazev, 49, Timiryazev street, Moscow, Moscow, 127550, Russian Federation;

phone: +7 (985) 994-02-20;

E-mail: kravchenko-in71@yandex.ru.

Evgeny O. Dobryshkin, Post-graduate student, Military Institute (engineering), Military Academy of Logistics named after Army General A.V. Khrulev, Zakharyevskaya st., 22, St. Petersburg, 191123, Russian Federation; phone: +7 (921) 555-97-02; e-mail: edobryshkin@mail.ru.

Yuri A. Biryukov, Doctoral student, Military Institute (engineering), Military Academy of Logistics named after Army General A.V. Khrulev, Zakharyevskaya st., 22, St. Petersburg, 191123, Russian Federation; phone: +7 (905) 255-36-97; e-mail: uabiryukov@mail.ru.

Valery I. Kondrashchenko, Doctor of technical sciences, professor of the Department of "Construction materials and technologies", Russian University of Transport (MIIT), Obraptsova Street, 9, 9b, Moscow, 127994, Russian Federation, phone +7 (926) 211-84-17;

E-mail: kondrashchenko@mail.ru

Бирюков Александр Николаевич, профессор, доктор технических наук, заведующий кафедрой; Военный институт (инженерно-технический), Военная академия материально-технического обеспечения имени генерала армии А.В. Хрулева (ВА МТО им. генерала армии А.В. Хрулева), ул. Захарьевская, 22, СанктПетербург, 191123, Российская Федерация;

Тел.: 8 (921) 751-67-52; e-mail: aleks_bir@mail.ru.

Кравченко Игорь Николаевич, профессор, доктор технических наук, профессор кафедры технического сервиса машин и оборудования, Российский государственный аграрный университет - МСХА имени К.А. Тимирязева, ул. Тимирязевская, 49, Москва, 1127550, Российской Федерации;

тел. +7 (985) 994-02-20;

E-mail: kravchenko-in71@yandex.ru.

Добрышкин Евгений Олегович, адъюнкт, Военный институт (инженерно-технический), Военная академия материально-технического обеспечения имени генерала армии А.В. Хрулева (ВА МТО им. генерала армии А.В. Хрулева), ул. Захарьевская, 22, СанктПетербург, 191123, Российская Федерация;

тел. +7 (921) 555-97-02; e-mail: edobryshkin@mail.ru.

Бирюков Юрий Александрович, докторант, Военный институт (инженерно-технический), Военная академия материально-технического обеспечения имени генерала армии А.В. Хрулева (ВА МТО им. генерала армии А.В. Хрулева), ул. Захарьевская, 22, СанктПетербург, 191123, Российская Федерация; тел.: +7 (905) 255-36-97; e-mail: uabiryukov@mail.ru.

Кондращенко Валерий Иванович, доктор технических наук, профессор кафедры «Строительные материалы и технологии» Российского университета транспорта, ул. Образцова, д. 9, стр. 9, Москва, 127994, Российская Федерация; тел. +7(926) 211-84-17;

E-mail: kondrashchenko@mail.ru. 